\title{
The levelling effect of product market competition on gender wage discrimination
}

\author{
Boris Hirsch ${ }^{1}$, Michael Oberfichtner ${ }^{2}$ and Claus Schnabel ${ }^{1 *}$
}

\author{
* Correspondence: \\ claus.schnabel@fau.de \\ ${ }^{1}$ University of Erlangen-Nuremberg, \\ Chair of Labour and Regional \\ Economics, Lange Gasse 20, 90403 \\ Nuremberg, Germany, and IZA, Bonn, \\ Germany \\ Full list of author information is \\ available at the end of the article
}

\begin{abstract}
Using linked employer-employee panel data for West Germany that include direct information on the competition faced by plants, we investigate the effect of product market competition on the gender pay gap. Controlling for match fixed effects, we find that intensified competition significantly lowers the unexplained gap in plants with neither collective agreements nor a works council. Conversely, there is no effect in plants with these types of worker codetermination, which are unlikely to have enough discretion to adjust wages in the short run. We also document a larger competition effect in plants with few females in their workforces. Our findings are in line with Beckerian taste-based employer wage discrimination that is limited by competitive forces.

JEL codes: J16, J31, J71

Keywords: Gender pay gap; Discrimination; Product market competition
\end{abstract}

\section{Introduction}

Studies documenting a significant, persistent gender pay gap are legion, as are studies relating this gap to wage discrimination in the labour market ${ }^{1}$. The usual theoretical approach to wage discrimination originates in the pathbreaking work by Becker (1971). According to Becker, discrimination stems from personal prejudices among employers, co-workers, or consumers that constitute discriminatory preferences among these groups. As a case in point, discriminatory employers may suffer a disutility from employing women. To be compensated for the loss in utility following from employing women, these employers pay lower wages to women than to men, ceteris paribus. In the non-segregating equilibrium, all female workers receive a lower wage than men, no matter whether they work for an employer with or without discriminatory preferences.

Yet, as pointed out by Arrow (1973), in equilibrium, non-discriminatory employers employ more women at below-productivity wages than their discriminatory counterparts and therefore gain a competitive advantage over their competitors. Put differently, indulging discriminatory preferences comes at a cost in this framework. Indeed, empirical studies have documented that discriminatory employers make lower profits (Hellerstein et al. 2002; Kawaguchi 2007) and are more likely to exit the market (Weber and Zulehner 2014). Employers actually seem to pay for discrimination.

For discrimination to prevail, discriminatory employers must possess some market power on their product markets, enabling them to indulge their costly preferences. Otherwise, discrimination would simply be competed away. And thus, the strength of

(C) 2014 Hirsch et al.; licensee Springer. This is an Open Access article distributed under the terms of the Creative Commons Attribution License (http://creativecommons.org/licenses/by/4.0), which permits unrestricted use, distribution, and reproduction in any medium, provided the original work is properly credited. 
product market competition should put limits on the viability of discrimination, with gender pay gaps being lower in more competitive environments. Following this line of reasoning, we investigate whether strong product market competition reduces gender wage discrimination in West Germany and whether this effect is more pronounced in the so-called codetermination-free sector, i.e., in plants with neither collective agreements nor a works council. In contrast with previous studies, we use linked employeremployee panel data that include a plant-level assessment of the strength of product market competition.

Almost exclusively, extant studies have used aggregate or indirect measures of competition such as the intensity of international trade (Black and Brainerd 2004; Juhn et al. 2014), the extent of market regulation (Black and Strahan 2001), market structure (Winter-Ebmer 1995; Heyman et al. 2013), or combinations of these (Jirjahn and Stephan 2006; Weichselbaumer and Winter-Ebmer 2007; Zweimüller et al. 2008; Heinze and Wolf 2010). Such measures, however, suffer from at least two severe shortcomings: First, although these proxies may be informative on the average intensity of product market competition within a product market, they do not provide information on changes in competitive pressure at the level of the individual firm where decisionmaking takes place. Even worse, using these measures requires the researcher to implicitly define plants' relevant product and geographical markets, which turns out to be far from trivial. Notably, the inevitable problems in doing so in a convincing and unambiguous way drove the German Monopolies Commission to cease reporting classic concentration measures, like the Herfindahl index or the concentration ratio, altogether (Monopolies Commission 2012, p. 12). Second, through the lens of the structure-conduct-performance paradigm, utilising these measures also claims that the market structure uniquely determines market participants' behaviour, thereby abstracting from different ways of competition on different product markets that may add further ambiguity to the proxy at hand. As a case in point, Sutton (1991) shows that fierce competition on a market with substantial entry costs may lead to high concentration in an industry (the limiting case being two incumbents competing $\grave{a}$ la Bertrand). To sidestep these problems related to aggregate or indirect proxies of product market competition, we will use a direct plant-level measure of competitive pressure based on a self-assessment by plants' managers. Therefore, we do not have to define plants' relevant market ex ante, and basing our measure on the beliefs of plants' managers about competition guarantees that it is relevant for managements' decision-making.

To the best of our knowledge, Belfield and Heywood (2006) and Hirsch et al. (2012) are the only scholars in this strand of the literature to base their evidence on direct information on the competition faced by individual firms. While Hirsch et al. (2012) find a negative correlation between firms' self-assessment on product market competition and the unexplained gender pay gap in West Germany, Belfield and Heywood (2006) document a negative link for the U.K. that is more pronounced in the non-unionised sector. Both studies, however, rely on cross-sectional data only - with Hirsch et al. (2012) utilising the 2008 cross section of the data set used in this study. They thus cannot rule out that differences in pay gaps, reflecting unobserved heterogeneity among firms facing different levels of product market competition and/or self-selection of workers into firms with different competitive pressure rather than a genuine competition effect. 
Against this background, our study contributes to the literature in three ways: First, our panel data permit us to investigate the impact of plant-level product market competition on the unexplained gender pay gap, controlling for match fixed effects, i.e., time-invariant unobserved heterogeneity for every plant-worker pair. We thus base our investigation on direct information on the competition faced by plants, with identification relying on the differential impact of within-plant variation in competitive pressure on within-plant wage growth of men and women. As a consequence, estimated effects are neither contaminated by unobserved time-invariant plant heterogeneity nor by self-selection of workers.

Second, apart from identification, we add to the literature by investigating heterogeneities in the competition effect on gender wage discrimination by plants' industrial relations regime. German industrial relations are characterised by a dual system of worker representation through (sectoral) trade unions and works councils that can be elected by the workforce in plants with at least five employees (for details, see Keller 2004 or Addison 2009). As plants' discretion to alter wages in response to changes in competitive pressure should be more limited if they are bound by a collective agreement or if they have a works council, we analyse whether the competition effect is stronger in the sector with none of these types of worker representation (which in Germany is usually referred to as the codetermination-free sector).

Third, we investigate whether the effect is larger in plants with a below-average share of females in their workforces. Since theory suggests that these plants have more pronounced discriminatory preferences, a stronger competition effect in these plants would further substantiate that fierce competition limits taste-based employer discrimination.

The remainder of this paper is organised as follows: Section 2 describes our data set and Section 3 our econometric approach. Section 4 presents and discusses our results, and Section 5 concludes.

\section{Data}

The data used in this paper consist of three waves of the cross-sectional model of the linked employer-employee data set of the Institute for Employment Research (LIAB) for the years 2008-2010 (for details, see Alda et al. 2005 and Heining et al. 2013). The data set links the IAB Establishment Panel, a representative survey of German plants (not companies), to the administrative data on all those individuals who work for these plants and contribute to the social insurance system.

The administrative data are based on the notification procedure for the German health, pension, and unemployment insurances. This requires all employers to report the necessary information on their workers if covered by the system, where misreporting is legally prohibited. Thus, among others, civil servants, self-employed, and individuals in marginal employment are not included. All in all, about 80 per cent of all people employed in Germany are covered by the social security system. Inter alia, the data include information for every worker on the daily gross wage, age, education, sex, nationality, tenure, occupation, and industry at the 30th of June of each year.

The employer side of our data comes from the IAB Establishment Panel (for details, see Kölling 2000), a stratified random sample of all plants that employ at least one worker covered by the social security system at the 30th June of each year. Starting in 
1993, the IAB Establishment Panel has surveyed plants from all industries in West Germany. Response rates of units that have been interviewed repeatedly exceed 80 per cent. Questions deal, among other things, with the number of workers, the composition of the workforce, the plant's commitment to collective agreements at the sector or plant level, the existence of a works council, the plant's exporting activity, and its production technology.

From 2008 onwards, the data additionally include a plant-level self-assessment of product market competition on a four-point Likert scale that enables us to distinguish plants facing strong competition from other plants ${ }^{2}$. Using this information, we set up a panel data set for West Germany in the years 2008-2010 to investigate the effect of product market competition on the gender pay gap in profit-oriented plants ${ }^{3}$.

Whereas the wage information included in the LIAB is highly reliable, there are two shortcomings of the data crucial to our investigation: Firstly, the data set includes daily wages only and no detailed information on working hours. As a consequence, we have to exclude part-time workers. Secondly, wages are top-coded at the social security contribution ceiling, which affects 16.2 per cent of our male and 6.0 per cent of our female observations. To deal with this second issue, we apply the standard single imputation procedure proposed by Gartner (2005) and impute top-coded wages. In a first step, we estimate yearly Tobit models for each combination of sex and competition (e.g., females working for plants facing strong competition), where the regressand is the log daily gross wage and the regressors are those included in the subsequent analysis. In a second step, for every observation with a top-coded wage, a random value is drawn from a normal distribution left-truncated at the respective social security contribution ceiling, with the predicted log wage as mean and the standard deviation as estimated from the Tobit models ${ }^{4}$.

All in all, we end up with a sample of 1,239,911 observations of 627,076 male workers and 305,876 observations of 166,759 female workers employed by 6,114 plants. As can be seen from Table 1, 66 per cent of male and 61 per cent of female observations belong to plants facing strong product market competition. Furthermore, 6 per cent of male and 10 per cent of female observations are in the codetermination-free sector, i.e., work in plants that are neither bound by collective agreements nor have a works council. Turning to wages, women earn about 21 per cent lower wages than men on average. This number hardly changes when considering the subgroups of workers working for plants facing strong or weak competition, though workers' wages are generally higher in plants with strong competitive pressure ${ }^{5}$. (For more descriptive statistics, see Table 2.)

As the transition matrix in Table 3 makes clear, plants' self-assessment on product market competition is extensively varied over time. During our period of observation, 1,715 transitions between strong and weak competition take place compared to 5,077 instances where competition stays constant. As a consequence, 23 per cent, or 171,369 out of 751,952 workers, are employed in plants with changing product market competition, thereby enabling us to rest identification on within-plant variation in competition. Notably, the number of transitions is not only reasonably large but is also roughly symmetrical with increases in competitive pressure being of similar magnitude as decreases. This renders it unlikely that plants with changing product market competition are a selective sample ${ }^{6}$. 
Table 1 Wages by sex and product market competition

\begin{tabular}{|c|c|c|c|c|}
\hline & \multicolumn{2}{|c|}{ Women } & \multicolumn{2}{|c|}{ Men } \\
\hline & Mean & Std. dev. & Mean & Std. dev. \\
\hline \multicolumn{5}{|l|}{ Full sample } \\
\hline Gross daily wages (in €) & 104.36 & 45.90 & 132.41 & 50.47 \\
\hline Log gross daily wages & 4.55 & 0.44 & 4.82 & 0.38 \\
\hline Strong product market competition (dummy) & 0.61 & 0.49 & 0.66 & 0.47 \\
\hline Codetermination-free plant (dummy) & 0.10 & 0.30 & 0.06 & 0.24 \\
\hline Observations & \multicolumn{2}{|c|}{305,876} & \multicolumn{2}{|c|}{$1,239,911$} \\
\hline Workers & \multicolumn{2}{|c|}{166,759} & \multicolumn{2}{|c|}{627,076} \\
\hline Plants & \multicolumn{4}{|c|}{6,114} \\
\hline \multicolumn{5}{|l|}{ Plants facing weak product market competition } \\
\hline Gross daily wages (in €) & 99.00 & 43.86 & 126.10 & 48.77 \\
\hline Log gross daily wages & 4.50 & 0.44 & 4.77 & 0.38 \\
\hline Codetermination-free plant (dummy) & 0.14 & 0.35 & 0.09 & 0.29 \\
\hline Observations & \multicolumn{2}{|c|}{120,176} & \multicolumn{2}{|c|}{424,971} \\
\hline \multicolumn{5}{|l|}{ Plants facing strong product market competition } \\
\hline Gross daily wages (in €) & 107.83 & 46.84 & 135.70 & 51.02 \\
\hline Log gross daily wages & 4.59 & 0.44 & 4.84 & 0.37 \\
\hline Codetermination-free plant (dummy) & 0.07 & 0.25 & 0.04 & 0.20 \\
\hline Observations & \multicolumn{2}{|c|}{185,700} & \multicolumn{2}{|c|}{814,940} \\
\hline
\end{tabular}

Notes: LIAB cross-sectional model, West Germany, 2008-2010. Wages are deflated by the consumer price index. Strong product market competition refers to the highest category on a four-point Likert scale of a plant-level self-assessment of competition.

Table 2 Descriptive statistics

\begin{tabular}{|c|c|c|c|c|}
\hline & & & & \\
\hline & Mean & Std. dev. & Mean & Std. dev. \\
\hline Potential experience (years) & 22.0 & 11.5 & 23.8 & 10.2 \\
\hline Tenure (years) & 10.7 & 8.6 & 13.2 & 9.3 \\
\hline Tenure censored (dummy) & 0.023 & 0.151 & 0.031 & 0.173 \\
\hline Apprenticeship, no Abitur (dummy) & 0.600 & 0.490 & 0.674 & 0.469 \\
\hline No apprenticeship, Abitur (dummy) & 0.021 & 0.142 & 0.010 & 0.102 \\
\hline Apprenticeship, Abitur (dummy) & 0.100 & 0.300 & 0.044 & 0.206 \\
\hline Technical college degree (dummy) & 0.040 & 0.195 & 0.070 & 0.255 \\
\hline University degree (dummy) & 0.071 & 0.257 & 0.086 & 0.280 \\
\hline Non-German nationality (dummy) & 0.069 & 0.254 & 0.074 & 0.261 \\
\hline Share of female workers & 0.399 & 0.239 & 0.211 & 0.159 \\
\hline Share of lowly qualified workers & 0.231 & 0.247 & 0.192 & 0.223 \\
\hline Works council (dummy) & 0.813 & 0.390 & 0.885 & 0.319 \\
\hline Collective bargaining at firm level (dummy) & 0.148 & 0.355 & 0.165 & 0.371 \\
\hline Collective bargaining at sector level (dummy) & 0.645 & 0.478 & 0.704 & 0.457 \\
\hline Exporting activity (dummy) & 0.607 & 0.488 & 0.767 & 0.423 \\
\hline New production technology (dummy) & 0.837 & 0.370 & 0.840 & 0.366 \\
\hline Plant in rural area (dummy) & 0.177 & 0.382 & 0.173 & 0.378 \\
\hline Plant size (number of workers) & 5,420 & 11,967 & 8,610 & 15,100 \\
\hline Observations & & & & \\
\hline
\end{tabular}

Notes: LIAB cross-sectional model, West Germany, 2008-2010. Tenure is left-censored if the worker's job with the plant started before 1975 . 
Table 3 Transitions between strong and weak product market competition

\begin{tabular}{|c|c|c|c|c|}
\hline \multirow[t]{3}{*}{ Initial product market competition } & \multicolumn{4}{|c|}{ Product market competition in the next period } \\
\hline & \multicolumn{2}{|c|}{ Plants } & \multicolumn{2}{|c|}{ Workers } \\
\hline & Weak $(t+1)$ & Strong $(t+1)$ & Weak $(t+1)$ & Strong $(t+1)$ \\
\hline Weak $(t)$ & 2,751 & 842 & 180,034 & 88,965 \\
\hline Strong $(t)$ & 873 & 2,326 & 82,404 & 400,549 \\
\hline
\end{tabular}

\section{Econometric Approach}

To test the hypothesis that product market competition lowers the gender pay gap, we will run augmented Mincerian wage regressions. Our baseline specification is a fully interacted model

$$
\ln w_{i j t}=\pi_{1} f e m_{i}+\pi_{2} \operatorname{comp}_{j t}+\pi_{3} \operatorname{comp}_{j t} \times f e m_{i}+\mathbf{x}_{i t}^{\prime}\left(\boldsymbol{\alpha}+\boldsymbol{\beta} \times f e m_{i}\right)+\mathbf{z}_{j t}^{\prime}\left(\boldsymbol{\gamma}+\boldsymbol{\delta} \times f e m_{i}\right)+\varepsilon_{i j t},
$$

where $\ln w_{i j t}$ is the $\log$ gross daily wage of worker $i$ working for plant $j$ in period $t$; fem $i$ is a female dummy, and comp $p_{j t}$ is a dummy indicating strong product market competition. comp $_{j t} \times f e m_{i}$ is the interaction of these two, and $\pi_{1}, \pi_{2}$, and $\pi_{3}$ are the corresponding coefficients. Furthermore, $\mathbf{x}_{i t}$ denotes a vector of worker characteristics, $\mathbf{z}_{j t}$ a vector of plant characteristics, $\varepsilon_{i j t}$ the idiosyncratic error component, and $\boldsymbol{\alpha}, \boldsymbol{\beta}, \boldsymbol{\gamma}$, and $\boldsymbol{\delta}$ are the corresponding coefficient vectors. In using a fully interacted model, we allow each worker and plant characteristic to affect men's and women's wages differently and thus exploit a more flexible framework than the earlier contributions by Belfield and Heywood (2006) and Hirsch et al. (2012), which also utilise plant-level measures of product market competition.

Worker controls comprise potential experience and tenure (both linearly and squared), dummy variables for joining the plant before 1975 (i.e. censored job tenure), five levels of education, non-German nationality, year of observation, and three-digit occupation. Plant controls include log plant size and its square, the shares of female and low-skilled workers in the plant's workforce, dummies for works council existence, a collective agreement at either firm level or sector level, exporting activity, new production technology, plant location in a rural area, and one-digit industry.

To ease interpretation, all regressors are centred around their sample averages, so that $\pi_{1}$ can be interpreted as the average unexplained gender pay gap in the full sample. The coefficients of main interest are $\pi_{2}$ and $\pi_{3}$, where $\pi_{2}$ gives the effect of strong product market competition on males' wages, and $\pi_{3}$ is the difference in the competition effect across the sexes. We expect strong competition to depress the overall rents accruing and thus workers' wages in general. Moreover, strong competition should also confine employers' ability to discriminate against women by sharing rents disproportionately with male workers (cf. Black and Strahan 2001). Hence, we expect $\pi_{2}$ to have a negative sign and $\pi_{3}$ to have a positive sign, the latter indicating that strong competition reduces the gender pay gap by inducing a smaller adverse effect on females' compared to males' wages.

In this baseline specification, identification rests on both inter-plant and within-plant variation in competition. It is therefore unclear whether the results are driven by 
unobserved plant heterogeneity correlated with plants' competitive pressure or by a genuine competition effect. To come closer to the true competition effect, we next add plant-sex fixed effects to the model, i.e., we control for permanent differences in plants' sex-specific wage policies. As discussed in Section 2, this is viable in our data because we have a sufficient number of plants with varying product market competition over time. Our second specification thus is

$\ln w_{i j t}=\pi_{2} \operatorname{comp}_{j t}+\pi_{3} \operatorname{comp}_{j t} \times f e m_{i}+\mathbf{x}_{i t}^{\prime}\left(\boldsymbol{\beta}+\boldsymbol{\gamma} \times f e m_{i}\right)+\mathbf{z}_{j t}^{\prime}\left(\boldsymbol{\alpha}+\boldsymbol{\delta} \times f e m_{i}\right)+v_{j}+\zeta_{j} \times f e m_{i}+\varepsilon_{i j t}$,

where the plant fixed effect for men and women is $v_{j}$ and $v_{j}+\zeta_{j}$, respectively ${ }^{7}$. In this second specification, identification of $\pi_{2}$ and $\pi_{3}$ relies on within-plant variation in competition and the accompanying changes in male and female workers' wages. Hence, $\pi_{2}$ tells us how males' wages and $\pi_{3}$ how the unexplained gender pay gap responds to intensified competition.

That said, changes in workers' wages due to varying competition may stem from two different sources: Either varying competition triggers wage changes for on-going jobs, i.e., for given worker-plant pairs, or wages change due to altering worker composition. And workers with different unobserved characteristics, like motivation, career outlook, or mobility, may self-select themselves into plants with different competitive pressure. As women and men have been found to differ considerably in both career aspirations and job mobility (e.g., Chevalier 2007 and Hirsch and Schnabel 2012), self-selection of workers may contaminate within-plant comparisons of unexplained gender pay gaps. In order to address self-selection of workers, we next include match fixed effects to our model, i.e., we control for the permanent wage component of every worker-plant pair. Hence, our third specification is given by

$$
\ln w_{i j t}=\pi_{2} \operatorname{comp}_{j t}+\pi_{3} \operatorname{comp}_{j t} \times f e m_{i}+\mathbf{x}_{i t}^{\prime}\left(\boldsymbol{\beta}+\boldsymbol{\gamma} \times f e m_{i}\right)+\mathbf{z}_{j t}^{\prime}\left(\boldsymbol{\alpha}+\boldsymbol{\delta} \times f e m_{i}\right)+\phi_{i j}+\varepsilon_{i j t}
$$

with match fixed effect $\phi_{i j}$. In this final specification, identification of $\pi_{2}$ and $\pi_{3}$ rests solely on changes in workers' within-plant wage growth, which is occurring simultaneously with within-plant variation in competition, i.e., wage changes within a given worker-plant pair. Estimated competition effects are thus free from biases stemming from unobserved heterogeneity in plants' permanent sex-specific wage policies and self-selection of workers with different unobserved time-invariant characteristics. A fall in workers' within-plant real wage growth may stem from various channels, such as decreased bonus payments, below-inflation nominal wage increases, or a reduction in the wage cushion between contract wages and effective wages.

We should make clear, though, that both specifications (2) and (3) just identify shortrun effects of product market competition on workers' wages, i.e., changes in wages occurring simultaneously with within-plant variation in competition. However, long-run effects, which we cannot identify given the short time horizon of our data, may be larger as it may take some time for employers to alter wages. Furthermore, plants' discretion to adjust wages in the short run is likely to differ depending on their industrial relations regime. Arguably, plants bound by legally binding collective agreements may find it harder to cut wages in response to intensified competitive pressure. In a similar 
vein, works councils are likely to protect workers' rents and lower plants' discretion to reduce wages in such an event ${ }^{8}$. We thus expect to find marked competition effects only in plants belonging to the codetermination-free sector.

\section{Results}

Running the three wage regressions (1)-(3) on our full sample yields the results summarised in Table 4. In the OLS specification, we find a highly significant average unexplained gender pay gap of 14.6 log points, which is similar in magnitude to previous studies for West Germany, such as Gartner and Hinz (2009) and Hirsch (2013). As can be seen from the estimated coefficient of the competition dummy, male workers' wages are $1.1 \mathrm{log}$ points lower in plants facing strong product market competition, which is statistically insignificant at conventional levels. The interaction effect of the female and the competition dummy indicates that the competition effect is almost zero and statistically insignificant. Note that the estimated coefficients of other regressors (which we do not report in Table 4 for the sake of brevity) show no surprises and are in line with the previous literature.

The picture hardly changes when resting identification on within-plant variation in competition in specifications (2) and (3). Intensified competition lowers male workers' wages by $0.8(0.9) \log$ points in the specification with plant-sex (match) fixed effects, where the coefficient is statistically significant at the $5(10)$ per cent level. Yet, the interaction effect of the female and the competition dummy is still very small and statistically insignificant throughout. So in the full sample, there is no indication of a differential short-run effect of intensified product market competition on female and male workers' wages and thus no evidence of a (levelling) competition effect on gender wage discrimination.

However, as discussed in Section 3, short-run effects are expected to be only visible in plants that possess enough discretion to adjust wages in the short run. We therefore think that effects are more likely to be visible in plants not subject to worker codetermination. To check this, we split our sample in two subsamples: plants bound by a collective

Table 4 Wage regressions (full sample)

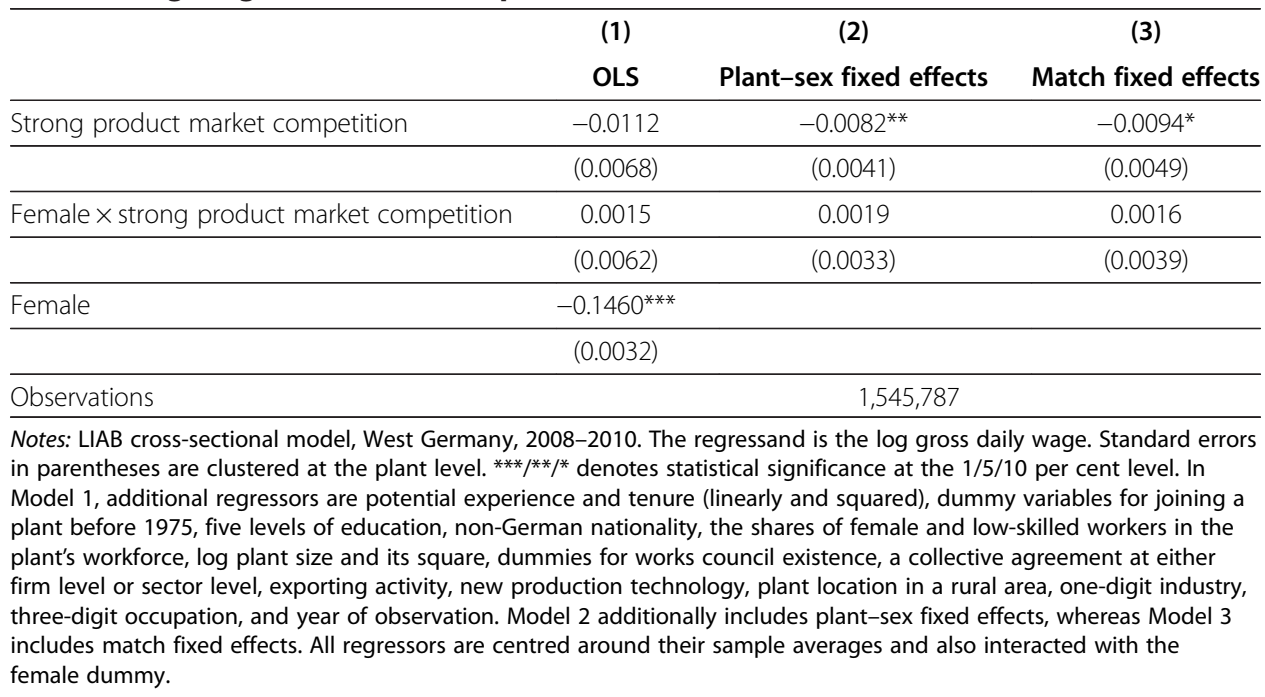


agreement and/or having a works council and codetermination-free plants. The results of running wage regressions on both subsamples are summarised in Table 5.

In line with earlier contributions, like Jirjahn and Stephan (2006) or Heinze and Wolf (2010), the unexplained gender pay gap is lower if some sort of worker codetermination is present. In the OLS specification (1), the gap amounts to $22.3 \log$ points in codetermination-free plants but just 14.7 log points in plants with worker codetermination. As expected, in codetermined plants workers' wages do not respond much to intensified competition. In the specifications with plant-sex or match fixed effects, an increase in competition causes male workers' wages to fall by $0.7-0.8 \log$ points, where the effect is statistically insignificant in the specification including match fixed effects. Furthermore, as the interaction effect is almost zero, there is clearly no differential effect across the sexes.

Results are different for the codetermination-free sector in which workers' wages are responding to intensified competition. This is in line with an earlier finding by Belfield and Heywood (2006) for the U.K. that the cross-sectional link between competition and the gap is driven by the non-unionised sector. Depending on specification, males' wages decrease by 1.5-3.2 log points if competition gets fierce, where all effects are statistically significant at least at the 5 per cent level. As the interaction effect indicates that women's wages are considerably less depressed than men's, the unexplained gender pay gap is significantly reduced by $1.2-2.1 \log$ points. In our preferred specification including match fixed effects and thus addressing unobserved plant heterogeneity and worker self-selection, intensified product market competition reduces males' wages by $1.9 \log$ points ${ }^{9}$, while females' wages are almost unaffected as the interaction effect also accounts to $1.8 \log$ points ${ }^{10}$. This is in line with our expectation that intensified competitive pressure reduces the rents accruing and thus restricts employers' ability to share rents

Table 5 Wage regressions by worker codetermination

\begin{tabular}{|c|c|c|c|}
\hline & (1) & $(2)$ & (3) \\
\hline & OLS & Plant-sex fixed effects & Match fixed effects \\
\hline \multicolumn{4}{|l|}{ Plants with some worker codetermination } \\
\hline \multirow[t]{2}{*}{ Strong product market competition } & -0.0092 & $-0.0073^{*}$ & -0.0077 \\
\hline & $(0.0072)$ & $(0.0043)$ & $(0.0049)$ \\
\hline \multirow[t]{2}{*}{ Female $\times$ strong product market competition } & -0.0002 & 0.0010 & -0.0006 \\
\hline & $(0.0066)$ & $(0.0034)$ & $(0.0037)$ \\
\hline \multirow[t]{2}{*}{ Female } & $-0.1471^{* * *}$ & & \\
\hline & $(0.0035)$ & & \\
\hline Observations & & $1,442,439$ & \\
\hline \multicolumn{4}{|l|}{ Codetermination-free plants } \\
\hline \multirow[t]{2}{*}{ Strong product market competition } & $-0.0320^{* * *}$ & $-0.0152^{* *}$ & $-0.0187^{* *}$ \\
\hline & $(0.0111)$ & $(0.0075)$ & $(0.0087)$ \\
\hline \multirow[t]{2}{*}{ Female $\times$ strong product market competition } & $0.0209^{*}$ & $0.0116^{*}$ & $0.0176^{* *}$ \\
\hline & $(0.0127)$ & $(0.0067)$ & $(0.0080)$ \\
\hline \multirow[t]{2}{*}{ Female } & $-0.2227^{* * *}$ & & \\
\hline & $(0.0250)$ & & \\
\hline Observations & & 103,348 & \\
\hline
\end{tabular}


disproportionately with male workers. Consequently, the unexplained gender pay gap falls by $1.8 \mathrm{log}$ points if competition gets fierce. As the average gap in codetermination-free plants accounts to $22.3 \log$ points, this means that it drops by about 8 per cent. Since this fall in the gap represents a short-run effect, and the long-run effect is arguably larger, we regard the competition effect on the gender pay gap as non-trivial from an economic point of view ${ }^{11}$.

To further scrutinise our results, we next split our sample by the share of females in plants' workforces. In Becker's (1971) model with taste-based employer discrimination, plants employing fewer women are not only more discriminatory employers but also less profitable. Therefore, we may expect the competition effect on the gender pay gap to be more pronounced in plants with a below-average share of female workers, which should be hit disproportionately by intensified product market competition.

To be precise, this notion is not literally true in Becker's (1971) original model where the gender pay gap is the same for all women, no matter whether they work for discriminatory or non-discriminatory employers. However, this latter conclusion of the model hinges on the assumption that workers can instantaneously and costlessly switch employers. Once one builds in some forces restricting worker mobility, it does not hold anymore. For instance, Bowlus and Eckstein (2002) incorporate discriminatory employer preferences into Mortensen's (1990) equilibrium search model with on-the-job search. They show that employers with more pronounced discriminatory preferences offer lower wages to women than employers with less pronounced tastes for discrimination and also end up with lower profits. Since intensified competition puts additional pressure on firm profitability, it restricts discriminatory employers' ability to pay for discrimination, and it does more so for more discriminatory employers who already make lower profits than their competitors. Hence, we expect the unexplained gender pay gap to fall to a larger extent in plants with a lower share of females in their workforces ${ }^{12}$.

To check whether the effect of competition on the unexplained gender pay gap is more pronounced in plants employing fewer women, we run wage regressions separately for workers employed by plants with below-average and plants with above-average shares of female workers (in the respective two-digit industry) ${ }^{13}$. Table 6 presents the estimated competition effects from our preferred specification with match fixed effects.

Table 6 Wage regressions with match fixed effects by worker codetermination and the share of females in plants' workforces

\begin{tabular}{lccc}
\hline & \multicolumn{3}{c}{ Effect of intensified product market competition on the } \\
& All plants & $\begin{array}{c}\text { Plants with worker } \\
\text { codetermination }\end{array}$ & $\begin{array}{c}\text { Codetermination- } \\
\text { free plants }\end{array}$ \\
\cline { 2 - 4 } & 0.0016 & -0.0006 & $0.0176^{* *}$ \\
\hline All plants & $(0.0039)$ & $(0.0037)$ & $(0.0080)$ \\
\hline Plants with below-average share of females & 0.0045 & 0.0028 & $0.0196^{* *}$ \\
\hline & $(0.0042)$ & $(0.0041)$ & $(0.0077)$ \\
\hline Plants with above-average share of females & 0.0008 & 0.0001 & -0.0026 \\
\hline & $(0.0033)$ & $(0.0036)$ & $(0.0061)$ \\
\hline
\end{tabular}

Notes: LIAB cross-sectional model, West Germany, 2008-2010. The regressand is the log gross daily wage. The coefficient shown is the interaction effect of the competition and the female dummy. Standard errors in parentheses are clustered at the plant level. ${ }^{* *} /{ }^{* *} /{ }^{*}$ denotes statistical significance at the $1 / 5 / 10$ per cent level. Regressors are those listed in Table 4. 
When not distinguishing plants depending on worker codetermination, intensified competition lowers the gender pay gap by $0.5 \mathrm{log}$ points in plants with a below-average female share, which is not statistically significant. This levelling effect of product market competition is somewhat smaller ( 0.3 log points) in plants with some worker codetermination and much larger ( 2.0 log points) and statistically significant at the 5 per cent level in codetermination-free plants. Remarkably, competition has no effect on the gender pay gap in plants with an above-average female share. Since, according to theory, plants with a below-average female share are more discriminatory employers, these findings are suggestive that intensified product market competition indeed reduces gender discrimination stemming from employer prejudices against women.

\section{Conclusions}

Using linked employer-employee panel data for West Germany for the years 20082010 that include a plant-level self-assessment on product market competition, we have investigated the effect of competition on the gender pay gap. In our preferred specification, we control for match fixed effects, thereby resting identification on the differential impact of within-plant variation in competitive pressure on within-plant wage growth of men and women. We thus address both unobserved time-invariant plant heterogeneity and worker self-selection into plants facing different levels of competition.

In line with Becker's (1971) model of taste-based employer discrimination where competition limits employers' ability to discriminate against women, we find that intensified competition significantly lowers the unexplained gender pay gap in plants without any worker codetermination by 1.8 percentage points. On the other hand, there is no levelling effect of competition in plants bound by collective agreements and/or that have a works council. There are three explanations for this latter finding that seem to be consistent with our evidence: First, institutions of codetermination may yield sluggish wage reactions, and longer-term estimates might show a response that mimics those without codetermination. Second, institutions of codetermination may resist any rent reduction (even if rents largely accrue to male workers). And third, institutions of codetermination may reduce the gender pay gap sufficiently on their own such that there is no added reduction associated with product market competition. While we do not have a strong preference for any of these explanations, we are also not aware of a convincing way how to discriminate among these in our data.

We also document that there is a more pronounced competition effect on the gender pay gap in plants with a below-average share of females in their workforces and that such an effect is generally absent in plants with an above-average female share. Since, according to theory, employers employing fewer women are more discriminatory, these findings are suggestive that competition indeed restricts gender wage discrimination, thus, reeling in employer prejudices against women.

Although we were able to improve on earlier contributions, particularly in terms of identification, the brief time horizon of our panel data only permited us to identify the short-run effect of product market competition on gender wage discrimination. While this short-run effect turned out to be non-trivial in magnitude, the long-run effect is likely to be larger, and we therefore regard our estimates as a lower bound of the competition effect. Investigating the long-run effect of product market competition on the gender pay gap seems to be a promising avenue for future research. 


\section{Endnotes}

${ }^{1}$ Weichselbaumer and Winter-Ebmer (2005) provide a large meta-analysis of more than 260 international studies on the gender pay gap between the 1960s and the 1990s.

${ }^{2}$ In our sample, 4.3 per cent of plants report "no pressure from competition at all", 11.1 per cent "minor pressure from competition", 38.5 per cent "medium pressure from competition", and 46.1 per cent "substantial pressure from competition", where we take the latter category as an indicator of strong competition in the plant's product market.

${ }^{3}$ Note that we do not find any impact of product market competition on both men's and women's wages when repeating our analysis for East Germany, which is in line with our earlier cross-sectional findings reported in Hirsch et al. (2012).

${ }^{4}$ As a check of robustness, we also redid our analysis excluding observations with top-coded wages from the sample, which did not change our insights.

${ }^{5} \mathrm{~A}$ multivariate analysis of the incidence of strong product market competition shows that plants facing strong competitive pressures are, ceteris paribus, larger, more often covered by collective agreements, and concentrated in (male-dominated) industries like manufacturing and construction. Hence, the descriptive evidence in Table 1 is likely to be driven by plant size, industry, and union effects.

${ }^{6}$ In addition to Table 3, Table 7 presents a detailed transition matrix for plants' selfassessed pressure from product market competition across the whole four-point Likert scale. It shows that less than 1 per cent of plants change from the highest to the lowest category or vice versa, while 95 per cent of transitions are between neighbouring categories, thereby mitigating concerns that changes in plants' self-assessed product market competition reflect inconsistent reporting. Moreover, excluding the few plants with extreme changes in product market competition in a check of robustness did not change our estimation results.

${ }^{7}$ Note that the coefficient of the female dummy $\pi_{1}$ is no longer identified when adding plant-sex or match fixed effects.

${ }^{8}$ Strictly speaking, German labour law precludes works councils from directly negotiating wages (which is the task assigned to trade unions). Yet, the extensive veto powers enjoyed by works councils in non-wage areas give them sufficient bargaining leverage to pressure management not to cut wages (cf. Addison et al. 2001).

${ }^{9}$ Note that male workers' wages drop somewhat less in the specification with plantsex fixed effects, suggesting that specification (2) misses part of the competition effect due to workers self-selecting into plants where accruing rents are large.

${ }^{10}$ Testing the effect of competition on females' wages, we also find that it is statistically insignificant in all three specifications (with $p$-values ranging from 0.38 to 0.78 ).

Table 7 Plant transitions between different levels of product market competition

\begin{tabular}{lcccc}
\hline $\begin{array}{l}\text { Initial pressure from product } \\
\text { market competition }\end{array}$ & \multicolumn{5}{c}{ Pressure from product market competition in the next period } \\
\cline { 2 - 5 } & No $(\boldsymbol{t}+\mathbf{1})$ & Minor $(\boldsymbol{t}+\mathbf{1})$ & Medium $(\boldsymbol{t}+\mathbf{1})$ & Substantial $(\boldsymbol{t}+\mathbf{1})$ \\
\hline No $(t)$ & 103 & 84 & 56 & 28 \\
\hline Minor $(t)$ & 49 & 275 & 292 & 92 \\
\hline Medium $(t)$ & 37 & 301 & 1,554 & 722 \\
\hline Substantial $(t)$ & 37 & 94 & 742 & 2,326 \\
\hline
\end{tabular}

Notes: LIAB cross-sectional model, West Germany, 2008-2010. 
${ }^{11}$ We also experimented with different definitions of strong product market competition. In particular, we defined strong competition comprising the two highest categories (rather than the single highest category) of plants' self-assessment of competition. Using this definition, 84.6 per cent of plants report strong product market competition, and only few changes between weak and strong product market competition take place (see Table 7). Redoing our analysis with this alternative indicator of strong product market competition, we find a similar sex difference in the impact of product market competition on workers' wages in codetermined and codetermination-free plants using the OLS specification, though this interaction effect is generally statistically insignificant as estimates are considerably less precise. Furthermore, estimates of specifications with either plant-sex or match fixed effects turned out to be too noisy to draw any conclusions, which is not that surprising given the few changes between strong and weak competition in this alternative definition of strong product market competition.

${ }^{12} \mathrm{We}$ are aware that a low share of females in plants' workforce may not only reflect employers' taste for discrimination but may also mirror that limited product market competition actually enables them to engage in costly discrimination against women.

${ }^{13}$ Note that we classify plants based on their time-average of the female share. Hence, we rule out that plants switch between groups, in particular due to changes in product market competition reflected in their workforce composition (see endnote 12).

\section{Competing interests}

The IZA Journal of Labor Economics is committed to the IZA Guiding Principles of Research Integrity. The authors declare that they have observed these principles.

\section{Acknowledgments}

We would like to thank Christian Dustmann, Andrea Weber, Thomas Zwick, three anonymous referees, and the editor of this journal for very useful suggestions. We further appreciate the comments received at the 2014 annual meetings of the Ausschuss für Bevölkerungsökonomie im Verein für Socialpolitik, the European Society for Population Economics, and the European Association of Labour Economists as well as the 2014 BGPE workshop. Writing of this paper has been partially supported by a BGPE scholarship to Michael Oberfichtner.

Responsible editor: Klaus F. Zimmermann

\section{Author details}

${ }^{1}$ University of Erlangen-Nuremberg, Chair of Labour and Regional Economics, Lange Gasse 20, 90403 Nuremberg, Germany, and IZA, Bonn, Germany. ${ }^{2}$ University of Erlangen-Nuremberg, Chair of Labour and Regional Economics, Lange Gasse 20, 90403 Nuremberg, Germany.

Received: 28 July 2014 Accepted: 23 October 2014

Published online: 31 December 2014

\section{References}

Addison JT (2009) The Economics of Codetermination: Lessons from the German Experience. Palgrave MacMillan, New York

Addison JT, Schnabel C, Wagner J (2001) Works councils in Germany: their effects on establishment performance. Oxf Econ Pap 53(4):659-694, doi:10.1093/oep/53.4.659

Alda H, Bender S, Gartner H (2005) The linked employer-employee dataset created from the IAB establishment panel and the process-produced data of the IAB (LIAB). Schmollers Jahrb 125(2):327-336

Arrow KJ (1973) The Theory of Discrimination. In: Ashenfelter OC, Rees A (eds) Discrimination in the Labor Market. Princeton University Press, Princeton, New Jersey, pp 3-23

Becker GS (1971) The Economics of Discrimination, 2nd edn. University of Chicago Press, Chicago, Illinois

Belfield C, Heywood JS (2006) Product Market Structure and Gender Discrimination in the United Kingdom. In: Heywood JS, Peoples JH (eds) Product Market Structure and Labor Market Discrimination. State University of New York Press, Albany, New York, pp 39-58

Black SE, Brainerd E (2004) Importing equality? The impact of globalization on gender discrimination. Ind Labor Relat Rev 57(4):540-559

Black SE, Strahan PE (2001) The division of spoils: rent-sharing and discrimination in a regulated industry. Am Econ Rev 91(4):814-831, doi:10.1257/aer.91.4.814

Bowlus AJ, Eckstein Z (2002) Discrimination and skill differences in an equilibrium search model. Int Econ Rev 43(4):1309-1345, doi:10.1111/1468-2354.t01-1-00057 
Chevalier A (2007) Education, occupation and career expectations. Oxf Bull Econ Stat 69(6):819-842, doi:10.1111/ j.1468-0084.2007.00483.x

Gartner H (2005) The Imputation of Wages Above the Contribution Limit With the German IAB Employment Sample. FDZ-Methodenreport 2/2005, Nuremberg

Gartner H, Hinz T (2009) Geschlechtsspezifische Lohnungleichheit in Betrieben, Berufen und Jobzellen (1993-2006). Berliner J für Soziol 19(4):557-575

Heining J, Scholz T, Seth S (2013) Linked Employer-Employee Data from the IAB: LIAB Cross-Sectional Model 2, 1993-2010 (LIAB QM2 9310). FDZ-Datenreport 2/2013, Nuremberg

Heinze A, Wolf E (2010) The intra-firm gender wage gap: a new view on wage differentials based on linked employeremployee data. J Popul Econ 23(3):851-879, doi:10.1007/s00148-008-0229-0

Hellerstein JK, Neumark D, Troske KR (2002) Market forces and sex discrimination. J Hum Resour 37(2):353-380, doi:10.2307/3069651

Heyman F, Svaleryd H, Vlachos J (2013) Competition, takeovers, and gender discrimination. Ind Labor Relat Rev 66(2):409-432

Hirsch B (2013) The impact of female managers on the gender pay gap: evidence from linked employer-employee data for Germany. Econ Lett 119(3):348-350, doi:10.1016/j.econlet.2013.03.021

Hirsch B, Oberfichtner M, Schnabel C (2012) Do women profit from competitive markets? Product market competition and the gender pay gap in Germany. Econ Bull 32(2):1618-1624

Hirsch B, Schnabel C (2012) Women move differently: Job separations and gender. J Labor Res 33(4):417-442, doi:10.1007/s12122-012-9141-1

Jirjahn U, Stephan G (2006) Gender and Wages in Germany: The Impact of Product Market Competition and Collective Bargaining. In: Heywood JS, Peoples JH (eds) Product Market Structure and Labor Market Discrimination. State University of New York Press, Albany, New York, pp 59-80

Juhn C, Ujhelyi G, Villegas-Sanchez C (2014) Men, women, and machines: How trade impacts gender inequality. J Dev Econ 106:179-193, doi:10.1016/j.jdeveco.2013.09.009

Kawaguchi D (2007) A market test for sex discrimination: evidence from Japanese firm-level data. Int J Ind Organ 25(3):441-460, doi:10.1016/j.jijndorg.2006.05.006

Keller BK (2004) Employment Relations in Germany. In: Bamber GJ, Lansbury RD, Wailes N (eds) International and Comparative Employment Relations: Globalisation and the Developed Market Economies. Sage, London, pp 211-253

Kölling A (2000) The IAB-establishment panel. Schmollers Jahrb 120(2):291-300

Monopolies Commission (2012) Summary of the nineteenth biennial report 2010/2011: strengthening competition in retailing and services. http://www.monopolkommission.de/images/PDF/HG/HG19/summary_h19.pdf. Accessed 14 Oct 2014

Mortensen DT (1990) Equilibrium Wage Distributions: A Synthesis. In: Hartog J, Ridder G, Theeuwes J (eds) Panel Data and Labor Market Studies. Elsevier, Amsterdam, pp 279-296

Sutton J (1991) Sunk Costs and Market Structure: Price Competition, Advertising, and the Evolution of Concentration. MIT Press, Cambridge, Massachusetts

Weber A, Zulehner C (2014) Competition and gender prejudice: Are discriminatory employers doomed to fail? J Eur Econ Assoc 12(2):492-521, 10.1111/jeea.12048

Weichselbaumer D, Winter-Ebmer R (2005) A meta-analysis of the international gender wage gap. J Econ Surv 19(3):479-511, 10.1111/j.0950-0804.2005.00256.x

Weichselbaumer D, Winter-Ebmer R (2007) The effects of competition and equal treatment laws on gender wage differentials. Econ Policy 22(4):235-287, 10.1111/j.1468-0327.2007.00177.x

Winter-Ebmer R (1995) Sex discrimination and competition in product and labour markets. Appl Econ 27(9):849-857, doi:10.1080/00036849500000038

Zweimüller M, Winter-Ebmer R, Weichselbaumer D (2008) Market orientation and gender wage gaps: an international study. Kyklos 61(4):615-635, 10.1111/j.1467-6435.2008.00419.x

\section{Submit your manuscript to a SpringerOpen ${ }^{\circ}$ journal and benefit from:}

- Convenient online submission

- Rigorous peer review

- Immediate publication on acceptance

- Open access: articles freely available online

- High visibility within the field

Retaining the copyright to your article

Submit your next manuscript at $\gg$ springeropen.com 